\title{
Food advertising on Argentinean television: are ultra-processed foods in the lead?
}

\author{
Lorena Allemandi ${ }^{1, *}$, Luciana Castronuovo ${ }^{1}, M$ Victoria Tiscornia ${ }^{1}$, Miguel Ponce ${ }^{2}$ and \\ Veronica Schoj ${ }^{2}$ \\ 'Department of Food Policy, Fundación InterAmericana del Corazón Argentina (FIC-Argentina), Arévalo 2364 - \\ 1 'A', Buenos Aires C1425DBR, Argentina: ${ }^{2}$ Fundación InterAmericana del Corazón Argentina (FIC-Argentina), \\ Buenos Aires, Argentina
}

Submitted 15 0ctober 2016: Final revision received 26 March 2017: Accepted 26 May 2017: First published online 26 July 2017

\begin{abstract}
Objective: To describe the number of processed and ultra-processed food (PUPF) advertisements (ads) targeted to children on Argentinean television (TV), to analyse the advertising techniques used and the nutritional quality of the foods advertised, and to determine the potential exposure of children to unhealthy food advertising in our country.

Design: Five free-to-air channels and the three most popular children's cable networks were recorded from 07.00 to 22.00 hours for 6 weeks. Ads were classified by target audience, type of product, advertised food categories and advertising strategies used. The NOVA system was used to classify food products according to industrial food processing level. Nutritional quality was analysed using the Pan American Health Organization's nutrient profile model.

Setting: Buenos Aires, Argentina. Results are considered applicable to most of the country.

Subjects: The study did not involve human subjects.

Results: Of the sample of food ads, PUPF products were more frequently advertised during children's programmes (98.9\%) $v$. programmes targeted to the general audience $\left(93.7 \%, \chi^{2}=45.92, P<0 \cdot 01\right)$. The top five food categories were desserts, dairy products, non-alcoholic sugary beverages, fast-food restaurants, and salty snacks. Special promotions and the appearance of cartoon characters were much more frequent in ads targeting children. Argentinean children are estimated to be exposed to sixty-one ads for unhealthy PUPF products per week. Conclusions: Our study showed that Argentinean children are exposed to a high number of unhealthy PUPF ads on TV. The Argentinean Government should build on this information to design and implement a comprehensive policy to reduce exposure to unhealthy food marketing that includes TV and other communication channels and places.
\end{abstract}

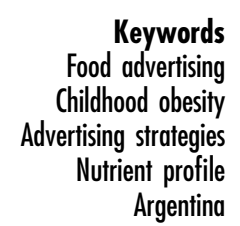

Childhood overweight and obesity are among the most serious public health problems in the world today. Estimates from the WHO showed that, in 2014, 41 million infants and young children were overweight or obese ${ }^{(1)}$. In Argentina, increases in the prevalence of overweight from 24.5 to $28.6 \%$, and of obesity from 4.4 to $5.9 \%$, have also been reported among teenagers between 13 and 15 years of age between 2007 and 2012 ${ }^{(2,3)}$. Data from 2007 estimated that obesity among Argentinean children under the age of 6 years was $10.4 \%{ }^{(4)}$.

One of the major causes of the global increase in the prevalence of childhood overweight and obesity and other diet-related non-communicable diseases over the past few years has been the increased intake of energy-dense foods ${ }^{(1)}$, mainly processed and ultra-processed foods (PUPF) ${ }^{(5,6)}$. This is due to their usually high content of sugar, salt and fats ${ }^{(7-9)}$, as well as their role in promoting unhealthy eating behaviours ${ }^{(10)}$. Over time, these readyto-eat food products have become more accessible to the public, leading to the situation today where the global food market is dominated by these products. Threequarters of global food sales, representing a total of at least $3 \cdot 2$ trillion US dollars, involve PUPF ${ }^{(11)}$.

While multiple factors affect the eating behaviours and food preferences of children and adolescents, one strong influence is food advertising; there is clear evidence that advertising of unhealthy foods has an impact on the types of food products that children prefer and consume, 
thus playing a significant role in the rise of overweight and obesity ${ }^{(12-15)}$. One of the most significant channels for delivering food advertising to children is television (TV). Although it is not the only one, evidence shows that exposure to advertising of unhealthy food products is one of the main links between TV viewing and childhood obesity ${ }^{(16)}$, particularly because young children are unable to detect the persuasive intent behind commercials on any media ${ }^{(17)}$. This makes children an easy target for advertisers. As a consequence, restrictions on TV advertising of these types of foods, particularly PUPF, could significantly reduce the prevalence of childhood overweight ${ }^{(18-20)}$. Any public health approach that attempts to tackle this problem should include advertising restrictions as a core policy ${ }^{(21-23)}$.

In 2010, the WHO asserted that the effectiveness of marketing messages can be measured through the level of exposure (i.e. reach, frequency and impact of the message) of target populations to the marketing message and marketing power (referring to the content, design and execution of the message). The effectiveness of marketing can thus be described as a function of both exposure and power $^{(24)}$. An analysis of food advertising to children should include both dimensions in order to reach an integrated understanding of the issue. The level of children's exposure to food TV advertising has been studied in several countries, showing that most food products advertised to children have poor nutritional quality ${ }^{(25-28)}$.

As it has been documented, the link between food advertising and childhood overweight/obesity varies from country to country ${ }^{(18)}$; thus the generation of local data on the amount of advertising of unhealthy foods Argentinean children are exposed to is crucial to design and promote country-tailored public policies to address childhood overweight and obesity. The purpose of the present study was to describe the current situation of food advertising of unhealthy foods targeted to children on TV, so as to contribute to policy-making efforts in Argentina and provide baseline data useful to track future progress in this area.

The specific study objectives were to: (i) document the number of TV food advertisements (ads) targeted to children on Argentinean TV; (ii) analyse the strategies and marketing techniques used in ads broadcast during children's programmes and examine differences between children's programmes and programmes targeted to the general audience; (iii) analyse types of food, types of processing and nutrient profiles of the foods advertised in children's TV programmes; and (iv) determine the potential exposure of children to unhealthy food advertisements from the most popular channels on Argentinean TV.

\section{Methods}

\section{Sample design}

We selected the three cable networks that, according to local ratings, were considered the most popular among children: Disney Channel, Disney XD and Cartoon Network. As of 2015, $80 \%$ of Argentinean households had cable $\mathrm{TV}^{(29)}$, which shows that these selected channels cover most of the country's territory. We also included five free-to-air TV networks: América TV, Canal 7, Canal 9, Telefe and Canal 13, since free-to-air TV is where companies spend most of their advertising funds according to the Argentinean Chamber of Media Agencies $^{(30)}$.

\section{Data collection}

Programmes on each selected channel were recorded by a media auditing service from 07.00 to 22.00 hours during two rotating weekdays and the weekend, for a total of 6 weeks. Data collection was conducted between November and December 2013 and January 2014.

A total of $1440 \mathrm{~h}$ of TV, including $132.5 \mathrm{~h}$ of advertising, were recorded and analysed by two coders following a standardized codebook ${ }^{(31)}$. Each ad was coded for time and date of airing, name of the programme, type of programme (children's $v$. general audience), company, brand, ad title and duration, and type of product. Programmes categorized as targeting children included all programmes broadcast on children's cable channels, as well as cartoons, series and game shows for children on free-to-air networks. Other shows aired on broadcast networks (series and films, documentaries, interviews, educational shows, sports, news programmes, etc.) were categorized as programmes targeting a general audience.

When the product consisted of a food product (including beverages), coders also categorized it within a food category and the advertising techniques used to advertise such product. All food and beverage ads were further evaluated for the use of persuasive techniques, including: (i) appealing to flavour/aroma/texture; (ii) appearance of male children/adolescents; (iii) appearance of female children/ adolescents; (iv) appearance of cartoon characters; (v) celebrity endorsements; (vi) special promotions and giveaways; (vii) featuring company or product websites; (viii) health/wellness references; and (ix) action/energy references. Coders were asked to record the primary appeal used in each commercial, with the understanding that a single ad could use several appeals simultaneously; a maximum of three primary appeal types could be assigned to any single ad. Past research was used as the basis for the development of categories used to describe and analyse the ads $^{(32-40)}$. These categories were piloted and refined prior to the study proper. The definition of variables may be consulted in our coders' handbook ${ }^{(31)}$.

To ensure consistency in data coding, an inter-rater reliability test was carried out ${ }^{(41,42)}$. Inter-rater reliability was determined through four successive pilot tests including sixty ads each. The pilot tests included five reliability coefficients: Cohen's kappa, Scott's pi, Krippendorff's alpha, Gwet's AC1 and Brenann-Prediger statistics. Variables with low inter-rater reliability values 
$(<0 \cdot 3)$ were either redesigned or eliminated from the data collection instrument and coders were retrained to ensure high inter-rater reliability scores $(>0 \cdot 8)$.

The coding process was conducted over a period of 5 months; the resulting database was consolidated and checked for inconsistencies before data analysis. Coders analysed data independently. Final inter-rater reliability scores ranged from $0 \cdot 8$ to $1 \cdot 0$.

Nutritional information on the advertised foods was extracted from a food composition database developed by Fundación InterAmericana del Corazón Argentina (FIC-Argentina) as part of other research studies ${ }^{(43)}$, which includes nutritional information for over 4000 food products available on the Argentinean market. For products advertised on TV that were not recorded in this database, nutritional information was obtained from the food labels of the products and/or from company websites $^{(26,40)}$. For products available in different presentations/flavours, nutritional information was analysed for all the product presentations depicted in the ad. In the case that the ad did not specify food items, all presentations were analysed to obtain an average nutritional content for that product, as has been conducted in prior studies $^{(26)}$. In the case of ads for fast-food restaurants, the most popular product (i.e. highest percentage of annual sales) was coded into the nutritional content database. The information was obtained directly from the company's website. Foods to be prepared at home (e.g. jelly powder, instant fruit drinks, soup powder) were coded considering $100 \mathrm{~g}$ or $100 \mathrm{ml}$ of the product ready for consumption $^{(32)}$.

\section{Classification of advertised food products: the NOVA system}

Two dimensions are analysed through the NOVA classification system: the food nutrient profiles and the level of $\operatorname{processing}^{(5,44)}$.

The NOVA system categorizes food products into four groups defined, according to the industrial processing involved in their production. Unprocessed or minimally processed foods (Group 1) include foodstuffs that have undergone mainly physical processes such as cleaning, freezing and pasteurization, reduction of fat content, and wrapping. These processes do not significantly alter the nature of the product. Examples are fresh or frozen meat, milk, vegetables, infusions, bottled water, etc. Processed culinary ingredients (Group 2) are typically inedible by themselves. These are common ingredients in both home-cooked meals and industrial food manufacturing. Examples include flours, oils and fats, sugar, corn syrup, lactose and refined proteins. Processed foods (Group 3) are manufactured by adding fats, oils, sugars, salt and other culinary ingredients to minimally processed foods to make them more durable and usually more palatable. These types of foods include simple breads and cheeses; salted and cured meats and seafood; and preserved fruits, legumes and vegetables. Ultra-processed foods (group 4) are industrial formulations manufactured from substances derived from foods or synthesized from other organic sources. They are inventions of modern industrial food science and technology. They are ready to consume or ready to heat, and thus require little or no culinary preparation ${ }^{(44)}$. Products were classified into the four processing categories in order to identify processed and non-processed products, excluding alcoholic beverages which are not considered in the NOVA system.

\section{Analysis of the nutritional quality of the foods advertised: the Pan American Health \\ Organization's nutrient profile model}

For the nutritional analysis of the foods advertised we used the Pan American Health Organization's (PAHO) nutrient profile model ${ }^{(45)}$. This model establishes maximum threshold contents for sugar (amount of energy from sugars $\geq 10 \%$ of the total amount of energy), salt (ratio between the amount of $\mathrm{Na}(\mathrm{mg})$ and the total amount of energy (kcal) $\geq 1: 114$ ), saturated fats (amount of energy from saturated fats $\geq 10 \%$ of the total amount of energy), trans fats (amount of energy from trans fats $\geq 1 \%$ of the total amount of energy) and total fat (the amount of energy from total fats $\geq 30 \%$ of the total amount of energy) in processed and ultra-processed food products ${ }^{(45)}$. Our analysis included processed and ultra-processed products.

\section{Data analysis}

Collected data were analysed to describe, by target audience (children's programmes $v$. general audience), the number of ads, total number of food products, number of PUPF and non-PUPF products, types of food categories advertised, advertising techniques used in the ads and the nutritional quality of the foods advertised. The analysis compared between children's programmes and programmes targeted to the general audience.

To analyse the potential exposure of Argentinean children to unhealthy food ads on TV we included data from IBOPE.* Argentinean children aged between 4 and 12 years watch $\mathrm{TV}$ for $3 \mathrm{~h} / \mathrm{d}$ on average during the peak viewing time (19.00 to 22.00 hours $)^{(29)}$. According to IBOPE, the channel with the highest ratings among Argentinean children is Disney Channel. We measured the frequency of PUPF ads during this time period on this channel.

The $\chi^{2}$ test was used to estimate differences in the variables between target audiences; $P$ values of $<0.05$ were considered statistically significant. All statistical analyses were conducted using the statistical software package IBM SPSS Statistics for Windows version 19.

\footnotetext{
* Kantar IBOPE Media provided rating measures by email on request.
} 


\section{Results}

From the $1440 \mathrm{~h}$ of recordings we coded a total of 21085 ads, 11228 during general audience programmes and 9857 during children's shows. These represented $25.5 \mathrm{~h}$ of advertising, $18.0 \mathrm{~h}$ of which were aired during general audience programmes and $7.5 \mathrm{~h}$ during children's programmes (Table 1).

The total sample included 3576 food ads ( $n$ 3340, excluding alcohol beverages according to the NOVA system), 2462 aired during general audience programmes and 1114 during children's programmes. Food ads were more frequent during general audience programmes than during children's programmes: $21.9 \%$ of ads aired during general audience programmes were for food products, compared with $11.3 \%$ of the ads aired during children's programmes $\left(\chi^{2}=65 \cdot 72, P<0 \cdot 01\right)$. However, PUPF products as categorized using the NOVA system constituted a larger proportion of the food ads aired during children's programmes (98.9\%) compared with those aired during programmes targeting the general audience $(93.7 \%$, $\left.\chi^{2}=45.92, P<0 \cdot 01\right)$. The proportions of ads for non-PUPF products were low in both audience categories (Table 2).

There were sixteen categories of PUPF products and four categories of non-PUPF products advertised to both audiences. The most frequently advertised PUPF products overall were non-alcoholic sugary beverages (35.3\%), cheese and yoghurt (12.2\%), desserts ( $8 \cdot 2 \%)$, salty snacks $(7 \cdot 4 \%)$ and sweets $(7 \cdot 4 \%)$. During programmes targeted to the general audience, the most advertised categories included non-alcoholic sugary beverages (45.9\%), cheese and yoghurts (9.7\%), sweets (9.0\%), salty snacks (7.2\%) and non-alcoholic non-sugary beverages (5.5\%). In children's programmes, the most frequently advertised PUPF products were desserts (21.6\%), cheese and yoghurts $(17 \cdot 4 \%)$, non-alcoholic sugary beverages $(13.8 \%)$, fast-food restaurants $(13.3 \%)$ and salty snacks (8.0\%; Table 3).

The analysis of advertising techniques used in PUPF product ads showed statistically significant differences between audience categories. In ads for PUPF products aired during children's programmes as compared with those targeting the general audience categories., we found that the advertising techniques more frequently used were those appealing to flavour/aroma/texture (55.8 v. $44.3 \%$, $\left.\chi^{2}=37.62, \quad P<0.01\right)$, the appearance of male $(44.0 \mathrm{v}$. $\left.38.8 \%, \chi^{2}=8.25, \quad P<0.01\right)$ or female $(40.1$ v. $26.3 \%$, $\left.\chi^{2}=63.50, P<0.01\right)$ children/adolescents, the appearance of cartoon characters $\left(44.0 v \cdot 4 \cdot 6 \%, \chi^{2}=746 \cdot 10, P<0 \cdot 01\right)$, special promotions and giveaways (33.5 v. 8.2\%, $\chi^{2}=324.96, P<0.01$ ), featuring company or product websites $\left(30 \cdot 7 v .20 \cdot 8 \%, \chi^{2}=38.66, P<0 \cdot 01\right)$ and action/energy references $\left(13.0 v .4 .4 \%, \chi^{2}=76.54, P<0.01\right)$. In contrast, PUPF product ads featuring celebrity endorsements and those referring to health and wellness were more frequent during general audience programmes than during children's programmes $\left(20.5 v .6 .1 \%, \chi^{2}=111.94, P<0.01\right.$ and 27.7 v. $20 \cdot 1 \%, \chi^{2}=21.93, P<0 \cdot 01$, respectively; Table 4).

Table 1 Number of advertisements (ads) aired on eight selected Argentinean television channels, November and December 2013 and January 2014 (n 21085), by audience category

\begin{tabular}{lccr}
\hline & Total & General audience & Child audience \\
\hline Number of ads & 21085 & 11228 & 9857 \\
Ads per channel & & & 91 \\
América TV & 3019 & 2928 & 460 \\
Canal 13 & 2643 & 2183 & 245 \\
Canal 7 & 1795 & 1550 & 394 \\
Canal 9 & 2847 & 2453 & 3307 \\
Cartoon Network & 3307 & 0 & 2394 \\
Disney Channel & 2394 & 0 & 2406 \\
Disney XD & 2406 & 2114 & 560 \\
Telefe & 2674 & 18.0 & 7.5 \\
Hours of ads analysed & 25.5 & & 0 \\
\hline
\end{tabular}

Table 2 Proportion and number of food advertisements (ads) aired on eight selected Argentinean television channels, November and December 2013 and January 2014 ( $n 21085$ ), by food processing level categorized according to the NOVA system and audience category

\begin{tabular}{|c|c|c|c|c|c|c|}
\hline & \multicolumn{2}{|c|}{$\begin{array}{c}\text { Total } \\
\text { (n } 21085)\end{array}$} & \multicolumn{2}{|c|}{$\begin{array}{c}\text { General audience } \\
\quad(n 11228)\end{array}$} & \multicolumn{2}{|c|}{$\begin{array}{l}\text { Child audience } \\
\quad(n \text { 9857) }\end{array}$} \\
\hline & $\%$ & $n$ & $\%$ & $n$ & $\%$ & $n$ \\
\hline Ads for food products $(\%)$ & $16 \cdot 96$ & 3576 & 21.93 & 2462 & $11 \cdot 30^{\star \star}$ & 1114 \\
\hline Ads for food products excluding alcohol (\%) & $15 \cdot 84$ & 3340 & 19.91 & 2236 & $11 \cdot 20^{\star \star}$ & 1104 \\
\hline Ads for PUPF (\% of food ads excluding alcohol) & 95.42 & 3187 & 93.69 & 2095 & $98 \cdot 91^{\star *}$ & 1092 \\
\hline Ads for non-PUPF (\% of food ads excluding alcohol) & 4.61 & 153 & $6 \cdot 30$ & 141 & $1.09^{\star *}$ & 12 \\
\hline
\end{tabular}

PUPF, processed and ultra-processed foods; non-PUPF, unprocessed or minimally processed foods.

Differences between audience categories were statistically significant: ${ }^{\star \star} P<0.01$. 
Table 3 Proportion of food advertisements (ads) aired on eight selected Argentinean television channels, November and December 2013 and January 2014 ( $n$ 3340), by food processing level categorized according to the NOVA system, food category and audience category

\begin{tabular}{|c|c|c|c|}
\hline Food processing level/food category & $\begin{array}{l}\% \text { of total food ads } \\
\qquad(n 3340)\end{array}$ & $\begin{array}{l}\% \text { of general audience food ads } \\
\qquad(n 2236)\end{array}$ & $\begin{array}{l}\% \text { of child audience food ads } \\
\qquad(n 1104)\end{array}$ \\
\hline \multicolumn{4}{|l|}{ PUPF } \\
\hline Cereal bars & $3 \cdot 2$ & $2 \cdot 1$ & $5 \cdot 5^{\star \star}$ \\
\hline Non-alcoholic, non-sugary beverages & 4.0 & 5.5 & $1 \cdot 2^{\star \star}$ \\
\hline Non-alcoholic, sugary beverages & $35 \cdot 3$ & $45 \cdot 9$ & $13 \cdot 8^{* *}$ \\
\hline Meats (canned tuna, turkey, etc.) & 0.7 & $1 \cdot 0$ & $0 \cdot 2^{\star \star}$ \\
\hline Breakfast cereal & $1 \cdot 1$ & 0.0 & $3 \cdot 4^{\star \star}$ \\
\hline Pre-prepared foods (soya patties, noodles, etc.) & 1.6 & $1 \cdot 8$ & $1 \cdot 3$ \\
\hline Flavour additives & $4 \cdot 3$ & 3.9 & $5 \cdot 0$ \\
\hline Hamburgers & 0.4 & $0 \cdot 2$ & $0 \cdot 8^{*}$ \\
\hline Sweets (candy, chocolates, etc.) & $7 \cdot 4$ & $9 \cdot 0$ & $4 \cdot 1^{\star \star}$ \\
\hline Cookies and crackers & 0.6 & 0.8 & 0.3 \\
\hline Cheese and yoghurt & $12 \cdot 2$ & $9 \cdot 7$ & $17 \cdot 4^{\star \star}$ \\
\hline Others & $1 \cdot 4$ & 1.4 & $15 \cdot 0$ \\
\hline Desserts & $8 \cdot 2$ & 1.6 & $21 \cdot 6^{\star \star}$ \\
\hline Fast-food restaurants & $5 \cdot 6$ & $1 \cdot 7$ & $13 \cdot 3^{\star *}$ \\
\hline Dressings & 1.9 & $2 \cdot 0$ & 1.6 \\
\hline Salty snacks & $7 \cdot 4$ & $7 \cdot 2$ & 8.0 \\
\hline \multicolumn{4}{|l|}{ Non-PUPF } \\
\hline Mineral water & 2.0 & 2.7 & $0 \cdot 5^{\star \star}$ \\
\hline Dry pasta & $2 \cdot 1$ & 2.9 & $0.5^{\star \star}$ \\
\hline Condiments (pepper, herbs, parsley, rosemary, etc.) & $0 \cdot 1$ & $0 \cdot 2$ & 0.0 \\
\hline Infusions & 0.4 & 0.6 & $0 \cdot 0^{\star}$ \\
\hline
\end{tabular}

PUPF, processed and ultra-processed foods; non-PUPF, unprocessed or minimally processed foods.

Proportions were significantly different from those of the general audience category: ${ }^{\star} P<0.05,{ }^{\star \star} P<0.01$.

Table 4 Advertising techniques employed in food advertisements (ads) for processed and ultra-processed (PUPF) food products aired on eight selected Argentinean television channels, November and December 2013 and January 2014 ( $n$ 3187), by audience category

\begin{tabular}{|c|c|c|c|}
\hline Advertising technique & $\begin{array}{l}\% \text { of total PUPF ads } \\
\qquad(n 3187)\end{array}$ & $\begin{array}{l}\% \text { of general audience PUPF ads } \\
\qquad(n \text { 2095) }\end{array}$ & $\begin{array}{l}\% \text { of child audience PUPF ads } \\
(n \text { 1092) }\end{array}$ \\
\hline Flavour/aroma/texture references & 48.2 & $44 \cdot 3$ & $55 \cdot 8^{\star \star}$ \\
\hline Appearance of male children/adolescents & $40 \cdot \overline{6}$ & 38.8 & $44 \cdot 0^{\star \star}$ \\
\hline Appearance of female children/adolescents & $31 \cdot 0$ & $26 \cdot 3$ & $40 \cdot 1^{\star \star}$ \\
\hline Health/wellness references & $25 \cdot 1$ & $27 \cdot 7$ & $20 \cdot 1^{\star *}$ \\
\hline Showing of product/company website & $24 \cdot 2$ & $20 \cdot 8$ & $30 \cdot 7^{\star \star}$ \\
\hline Cartoon characters & $18 \cdot 1$ & 4.6 & $44 \cdot 0^{\star \star}$ \\
\hline Celebrity endorsement & $15 \cdot 5$ & 20.5 & $6 \cdot 1^{\star *}$ \\
\hline Promotions and giveaways & $16 \cdot 8$ & 8.2 & $33 \cdot 5^{\star \star}$ \\
\hline Event sponsorship & 8.7 & $8 \cdot 3$ & 9.3 \\
\hline Action/energy references & $7 \cdot 4$ & 4.4 & $13 \cdot 0^{\star *}$ \\
\hline
\end{tabular}

Proportions were significantly different from those of the general audience category: ${ }^{\star \star} P<0.01$.

From the final sample of food ads ( $n$ 3340), the analysis of nutritional quality using the PAHO nutrient profile model included 2959 PUPF ads. Of this total number, 93.1\% ( $n$ 2755) had an excessive content of energy and/or one or more nutrients (i.e. total fat, saturated fat, trans fats, sugar and salt). Products with excessive content of at least one of these nutrients represented $91.0 \%$ ( $n$ 939) of the PUPF products advertised during children's programmes and $94.2 \%$ ( $n$ 1816) of the PUPF advertised during general audience programmes (Fig. 1). This difference was statistically significant $\left(\chi^{2}=11.07, P<0 \cdot 01\right)$.

Estimates of potential exposure of children to unhealthy food ads showed that children aged 4 to 12 years are exposed to a weekly average of sixty-one ads for PUPF products with low nutritional value.

\section{Discussion}

The current study focused on the advertising of food products, using both the NOVA system and the PAHO nutrient profile model. The study has improved understanding of the marketing of food products to children on Argentinean TV, the nutritional value of the products advertised and the advertising techniques used to capture children's interest and influence their food choices.

We found that most of the food items advertised on Argentinean TV fell into the category of PUPF products, with little to no advertising of natural, unprocessed foods such as milk, fruits and vegetables both in programmes targeted to the general audience and in programmes targeted to children. This shows that foods advertised on TV do not agree 


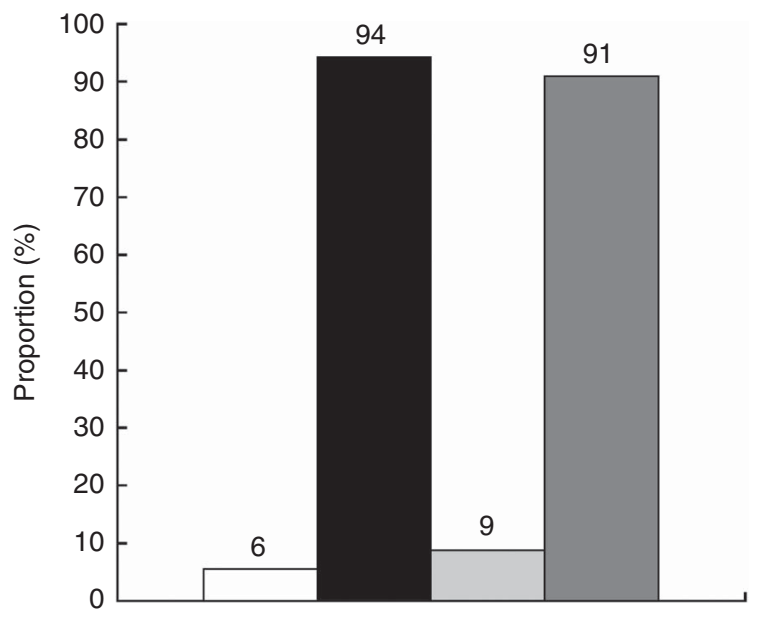

Fig. 1 Proportion of products with an excessive content of at least one nutrient (i.e. energy, total fat, saturated fat, trans fat, sugar and/or salt) $\dagger$ in food advertisements for processed and ultra-processed (PUPF) food products aired on eight selected Argentinean television channels, November and December 2013 and January 2014 ( $n$ 3187), by audience category: $\square$, general audience, no excesses; $\square$, general audience, one or more excesses; $\square$, child audience, no excesses; $\square$, child audience, one or more excesses. †Nutritional quality analysed using the Pan American Health Organization's nutrient profile model

with the recommendations of the Argentinean Dietary Guidelines $^{(46)}$ to promote increased consumption of natural and home-made foods and to limit intake of PUPF products.

These findings are in line with other studies conducted in the Latin American region ${ }^{(27,38,39,47)}$ indicating that unhealthy food products are aggressively marketed on TV, both in terms of the number of ads and the advertising strategies used. Our results are also similar to those from studies conducted in other countries that found that sugary beverages, salty snacks and fast foods are within the top five food categories marketed to children ${ }^{(48,49)}$. Most of these products have excessive content of at least one of the critical nutrients according to the PAHO nutrient profile model. This is also consistent with the scientific evidence that shows that the products more frequently marketed to children fail to meet the current recommendations on healthy eating habits ${ }^{(50)}$.

The proportion of PUPF ads and the use of particularly powerful advertising strategies, such as premiums/giveaways and appearance of cartoon characters, were significantly more frequent in ads broadcast during children's programmes. In our sample, one out of four ads used cartoon characters and one out of three used promotions to capture children's attention. There is sound evidence on how the use of these types of strategies influences food choices and consumption patterns, especially among children $^{(14,15,51,52)}$. Exposure to these ads causes children to consider these products as more attractive than other healthier - food options ${ }^{(53)}$.

There is sufficient scientific evidence showing that food advertising exerts a powerful influence not only on children's food preferences, but also on their food intake, food purchase requests ${ }^{(54)}$ and their weight ${ }^{(55)}$. Therefore, reducing exposure of children to unhealthy food advertising is one of the most cost-effective measures to tackle the childhood overweight/obesity epidemic ${ }^{(50)}$. However, our results suggest that, at least in Argentina, these reductions should not be limited to programmes categorized as 'children's programmes' broadcast on TV networks, since unhealthy food ads are more frequent during programmes targeting the general audience than in children's programmes. If we assume that advertising influences consumer choices in general, the pervasiveness of unhealthy food marketing on TV may contribute to the overall obesogenic environment by influencing the types of foods that parents buy and make available to their family at home.

Moreover, ratings data from September 2016 for the five free-to-air television networks in Argentina indicate that from the twenty programmes most popular among children, eighteen are programmes targeted to the general audience. Also, from the total number of programmes aired on free-to-air television networks, $89 \%$ are programmes targeting the general audience. This demonstrates that children are not only exposed to ads aired during children's programmes but also to those aired during programmes targeted to the general audience (IBOPE, personal communication, September 2016).

In this context, the use of powerful advertising techniques to promote low nutritional quality food products in programmes targeted to the general audience also has a direct impact on children's consumption choices. Approximately half of food product ads broadcast in this audience are for sugary beverages, whose impact on childhood overweight, obesity and diabetes is well documented ${ }^{(56)}$. The potential exposure of children to advertising of these products is alarming, particularly in a country like Argentina where the consumption of sugar is triple the international recommended daily intake ${ }^{(57)}$. Considering the results presented here and the information about ratings facilitated by IBOPE, children are potentially exposed to an average of sixty-one ads for PUPF products with low nutritional value on TV per week. These findings are consistent with those obtained in other countries $^{(16)}$.

Although countries such as Chile, Mexico, South Korea and the UK have put forth policies to regulate unhealthy food advertising, these measures often contain legal loopholes and fail to effectively protect children from exposure to this advertising ${ }^{(58)}$. Although these regulations are an important base they are not enough to protect children's right to health and should be updated to include all new marketing techniques.

In Argentina, there are public policies that attempt to protect children from deceitful commercials or from the advertising of harmful products. Some examples include the Consumer Protection Act 24240 (1993), the Audiovisual Services Act 26522 (2009) and the Commercial 
Loyalty Act $22082(1983)^{(59-62)}$. These policies have not been specifically designed to limit exposure of children to food marketing from a public health perspective. Rather, they have been included in a more general framework of consumers' rights protection. As another example, in September 2015 the ANMAT (National Drug, Food and Medical Technology Administration) issued a regulation to enforce monitoring of food and drug advertising in order to assert that the information provided therein is 'truthful and objective' and that it does not promote 'unhealthy behavior and/or habits ${ }^{, 62)}$. The regulation does not contemplate any specifications as to how to determine whether a particular product should be considered unhealthy or not, nor does it establish any a priori restriction on the advertising of food product categories.

As shown above, exposure of Argentinean children to advertising of PUPF products is very high and disproportionate to that of healthy and natural food products. It is essential for Argentina to promote and design an effective policy to protect children from this influence and to promote consumption of healthy food products. Such a policy should include not only channels or programmes that explicitly target children but also those targeting the general audience, as well as other media such as the Internet, particularly new media scenarios and marketing strategies. Several studies conclude that it is necessary to have a comprehensive policy that regulates all media and communication channels ${ }^{(58)}$. Experiences suggest that partial restrictions on advertising in certain media, or at specific times, result only in greater exposure from other media and at other times ${ }^{(63)}$, as the food industry shifts its advertising expenditure from the restricted to the unrestricted forms of advertising. This also happened when partial tobacco advertising restrictions were introduced that applied only to radio and television advertising ${ }^{(64)}$.

One of the strengths of the present study is that data generated here will contribute to the understanding of TV food marketing characteristics in Argentina and to the setting of a baseline against which future progress can be measured. Also, the study is innovative in applying the NOVA system and the PAHO nutrient profile model in Argentina to assess the nutritional quality of food products advertised on TV. This will allow for comparison with other countries in Latin America and potentially facilitate a regional approach to curb childhood obesity. Finally, because of the sampling design that included a large sample of ads from different channels, the study has a wide scope that guarantees its representativeness of the situation of TV food ads in Argentina. However, the study also presents limitations. By focusing only on TV advertising, our results may underestimate the overall level of exposure of children and adolescents to food ads in general. However, we decided to begin our research on exposure of children to food advertising by focusing on TV for two reasons. First, as explained above, there is solid evidence that time spent watching TV and exposure to unhealthy food ads on TV are associated with children consuming more of the advertised foods (which are overwhelmingly unhealthy). Second, although advertising is shifting to other media, such as the Internet, in the year 2014-2015 TV remained a frequently used medium for marketing purposes. Estimates of advertising expenditure in Argentina indicate that TV spending was 39.5\% of total advertising expenditure in 2014 and $38.5 \%$ over the period 2014-2015, while Internet marketing expenditure was $15 \cdot 9$ to $20 \cdot 4 \%{ }^{(30)}$.

The current study is the first that describes the extent and power of food advertising on Argentinean TV; we considered this to be a good starting point to generate scientific knowledge about food marketing in our country, with the specific purpose of contributing to public health policy dialogues. In fact, we have already contributed to this process by sharing and discussing our results with policy makers in several forums.

Future research should explore other communication means, such as product placement within programmes, social media and the Internet, in order to accurately assess exposure to unhealthy food advertising in the country. We hope to contribute to this effort.

\section{Conclusions}

Our study showed that Argentinean children are exposed to a high number of ads for PUPF products, most of which should not be permitted to be marketed to children due to their excessive content of energy, saturated and trans fats, sugar and/or salt. Moreover, more powerful marketing strategies, such as promotions and celebrity endorsements, are used in ads aired during TV programmes targeting children. The Argentinean Government could build on this information to design and implement a comprehensive policy to reduce exposure to the advertising of these unhealthy products to children, in line with the recommendations issued by WHO and PAHO to tackle the childhood obesity epidemic. Such policies should not be limited to children's programmes and should also be applied in other communication channels such as the Internet, new media scenarios and to food packages.

\section{Acknowledgements}

Acknowledgements: The authors thank Malena Pirola for her assistance in writing the manuscript and the rest of FIC-Argentina's team for their contribution during the conduct of this study. They also thank Maria Lia Ghelfi and Gisela Becerra for their assistance in data coding. Financial support: This work was supported by the International Development Research Center (IDRC; grant number 107459-001): 'Food advertising to children in Argentinean television: a quantitative and qualitative 
analysis'. IDRC had no role in the design, analysis or writing of this article. Conflict of interest: none. Authorship: L.A. was responsible for the research design, data collection and data entry process, interpretation of results and writing of the manuscript. L.C. and M.V.T. contributed to the elaboration of the data collection instrument, elaboration of the manual for coders, training of coders and supervision of the data collection process, participated in interpretation of results and revised the manuscript. M.P. conducted data analysis and assisted in interpreting results. V.S. designed the overall strategy, supervised all the phases of this study and provided substantive review of the manuscript. Ethics of human subject participation: The study did not involve human subjects.

\section{References}

1. World Health Organization (2015) Obesity and overweight, Factsheet no. 311. http://www.who.int/mediacentre/ factsheets/fs311/en/ (accessed March 2016).

2. Ferrante D, Linetzky B, Ponce M et al. (2014) Prevalencia de sobrepeso, obesidad, actividad física y tabaquismo en adolescentes argentinos: Encuestas Mundiales de Salud Escolar y de Tabaco en Jóvenes, 2007-2012. Arch Argent Pediatr 112, 500-504.

3. Linetzky B, Morello P, Virgolini M et al. (2011) Resultados de la primera encuesta nacional de salud escolar: Argentina, 2007. Arch Argent Pediatr 109, 111-116.

4. Durán P, Mangialavori G, Biglieri A et al. (2009) Estudio descriptivo de la situación nutricional en niños de 6-72 meses de la República Argentina: resultados de la Encuesta Nacional de Nutrición y Salud (ENNyS). Arch Argent Pediatr 107, 397-404.

5. Monteiro CA (2009) The issue is not food, nor nutrients, so much as processing. Public Health Nutr 12, 729-731.

6. Baker P \& Friel S (2014) Processed foods and the nutrition transition: evidence from Asia. Obes Rev 15, 564-577.

7. Canella DS, Levy RB, Martins APB et al. (2014) Ultra-processed food products and obesity in Brazilian households (2008-2009). PLoS One 9, e92752.

8. da Costa Louzada ML, Baraldi LG, Steele EM et al. (2015) Consumption of ultra-processed foods and obesity in Brazilian adolescents and adults. Prev Med 81, 9-15.

9. Moubarac J-C, Martins APB, Claro RM et al. (2013) Consumption of ultra-processed foods and likely impact on human health. Evidence from Canada. Public Health Nutr 16, 2240-2248.

10. Monteiro CA, Gomes FS \& Cannon G (2010) The snack attack. Am J Public Health 100, 975-981.

11. Bielemann RM, Motta JVS, Minten GC et al. (2015) Consumption of ultra-processed foods and their impact on the diet of young adults. Rev Saude Publica 49, 28.

12. Zimmerman FJ \& Bell JF (2010) Associations of television content type and obesity in children. Am J Public Health 100, 334-340.

13. Utter J, Scragg R \& Schaaf D (2006) Associations between television viewing and consumption of commonly advertised foods among New Zealand children and young adolescents. Public Health Nutr 9, 606-612.

14. Magnus A, Haby M, Carter R et al. (2009) The costeffectiveness of removing television advertising of high-fat and/or high-sugar food and beverages to Australian children. Int J Obes (Lond) 33, 1094-1102.

15. Hastings G, Stead M, McDermott L et al. (2003) Review of Research on the Effects of Food Promotion to Children. Final
Report prepared for the Food Standards Agency. Glasgow: Centre for Social Marketing; available at https://goo.gl/sHfCZp

16. Kelly B, Smith B, King L et al. (2007) Television food advertising to children: the extent and nature of exposure. Public Health Nutr 10, 1234-1240.

17. Kunkel D, Wilcox BL, Cantor J et al. (2004) Psychological Issues in the Increasing Commercialization of Childhood. Report of the APA Task Force on Advertising and Children. Washington, DC: American Psychological Association.

18. Chou S-Y, Rashad I \& Grossman M (2008) Fast food restaurant advertising on television and its influence on childhood obesity. J Law Econ 51, 599-618.

19. Goris JM, Petersen S, Stamatakis E et al. (2010) Television food advertising and the prevalence of childhood overweight and obesity: a multicountry comparison. Public Health Nutr 13, 1003-1012.

20. Veerman JL, Van Beeck EF, Barendregt JJ et al. (2009) By how much would limiting TV food advertising reduce childhood obesity? Eur J Public Health 19, 365-369.

21. World Health Organization (2003) Diet, Nutrition and the Prevention of Chronic Diseases. Report of a Joint WHO/FAO Expert Consultation. WHO Technical Report no. 916. Geneva: WHO; available at https://goo.gl/TG9fcF

22. World Health Organization (2013) Global Action Plan for the Prevention and Control of NCDs 2013-2020. Geneva: WHO; http://www.who.int/nmh/events/ncd_ action_plan/en/

23. Pan American Health Organization (2015) Plan of Action for the Prevention of Obesity in Children and Adolescents. Washington, DC: PAHO; available at https://goo.gl/TG9fcF

24. World Health Organization (2010) Set of Recommendations on the Marketing of Foods and Non-alcoholic Beverages to Children. Geneva: WHO; available at http://apps.who.int/ iris/bitstream/10665/44416/1/9789241500210_eng.pdf

25. Keller SK \& Schulz PJ (2010) Distorted food pyramid in kids' programmes: a content analysis of television advertising watched in Switzerland. Eur J Public Health 21, 300-305.

26. Romero-Fernandez MM, Royo-Bordonada MA \& Rodríguez-Artalejo F (2013) Evaluation of food and beverage television advertising during children's viewing time in Spain using the UK nutrient profile model. Public Health Nutr 16, 1314-1320.

27. Rincón-Gallardo Patiño S, Tolentino-Mayo L, Monterrubio EAF et al. (2016) Nutritional quality of foods and non-alcoholic beverages advertised on Mexican television according to three nutrient profile models. BMC Public Health 16, 733.

28. Boyland EJ, Harrold JA, Kirkham TC et al. (2011) The extent of food advertising to children on UK television in 2008. Int $J$ Pediatr Obes 6, 455-461.

29. Latin American Multichannel Advertising Council (2015) TV paga en Argentina. http://www.lamac.org/res/news/TVPaga-Argentina-2015.pdf (accessed October 2016).

30. Cámara Argentina de Agencias de Medios (2015) Evolución de la Actividad Publicitaria Argentina. http://www.agen ciasdemedios.com.ar/inversiones-publicitarias/inversiones2015/ (accessed March 2017).

31. Fundación InterAmericana del Corazón Argentina (2014) Estudio de investigación 'Publicidad de alimentos dirigida a niños en la TV argentina: análisis cualicuantitativo'. Manual de capacitación para el codificador. http://www.ficargentina.org/images/stories/Documentos/manual_codificadores. pdf (accessed March 2017).

32. Castillo-Lancellotti C, Pérez-Santiago O, Rivas-Castillo C et al. (2010) Análisis de la publicidad de alimentos orientada a niños y adolescentes en canales chilenos de televisión abierta. Rev Esp Nutr Comun 16, 90-97.

33. Kunkel D \& Gantz W (1992) Children's television advertising in the multichannel environment. $J$ Commun $\mathbf{4 2}$, 134-152. 
34. Consumers International (2011) Manual de monitoreo de la promoción de alimentos dirigida a los niños. London: Consumers International; available at http://www.consumersinternational.org/media/795246/food-manual-spanishweb.pdf

35. Connor SM (2006) Food-related advertising on preschool television: building brand recognition in young viewers. Pediatrics 118, 1478-1485.

36. Gantz W, Schwartz N, Angelini JR et al. (2007) Food for Thought: Television Food Advertising to Children in the United States. Menlo Park, CA: Kaiser Family Foundation.

37. Lewis M \& Hill A (1998) Food advertising on British children's television: a content analysis and experimental study with nine-year olds. Int J Obes Relat Metab Disord 22, 206-215.

38. Pérez-Salgado D, Rivera-Márquez JA \& Ortiz-Hernández L (2010) Publicidad de alimentos en la programación de la televisión mexicana: ¿̇los niños están más expuestos? Salud Publica Mex 52, 119-126.

39. Uribe Bravo R (2012) 'Un momento y ya volvemos': un análisis de contenido de la publicidad infantil en la televisión chilena. Comun Soc 18, 79-106.

40. Jenkin G, Wilson N \& Hermanson N (2009) Identifying 'unhealthy' food advertising on television: a case study applying the UK Nutrient Profile model. Public Health Nutr 12, 614-623.

41. Gwet KL (2010) Handbook of Inter-Rater Reliability. The Definitive Guide to Measuring the Extent of Agreement Among Raters, 2nd ed. Gaithersburg, MD: Advanced Analytics LLC.

42. Cicchetti DV \& Feinstein AR (1990) High agreement but low kappa: II. Resolving the paradoxes. J Clin Epidemiol 43, 551-558.

43. Allemandi L, Tiscornia MV, Ponce M et al. (2015) Sodium content in processed foods in Argentina: compliance with the national law. Cardiovasc Diagn Ther 5, 197.

44. Monteiro C, Cannon G, Levy RB et al. (2012) The food system. Ultra-processing. The big issue for nutrition, disease, health, well-being. World Nutr 3, 527-569.

45. Pan American Health Organization (2016) Nutrient Profile Model. Washington, DC: PAHO; available at https://goo.gl/ wOsTCM

46. Ministerio de Salud de la Nacion Argentina (2016) Guías alimentarias para la población argentina (Dietary guidelines for the Argentinean population). https://goo.gl/6BgokV (accessed July 2017).

47. Monteiro R, Coutinho J \& Recine E (2008) Monitoração de Propaganda de Alimentos Visando à Prática da Alimentação Aaudável. Brasília: Universidade de Brasília Observatório de Políticas de Segurança Alimentar e Nutrição.

48. Kelly B, Halford JC, Boyland EJ et al. (2010) Television food advertising to children: a global perspective. Am J Public Health 100, 1730-1736.

49. Outley CW \& Taddese A (2006) A content analysis of health and physical activity messages marketed to African American children during after-school television programming. Arch Pediatr Adolesc Med 160, 432-435.

50. Pan American Health Organization (2011) Recommendations from a Pan American Health Organization Expert
Consultation on the Marketing of Food and Non-Alcobolic Beverages to Children in the Americas. Washington, DC: PAHO; available at https://goo.gl/LI32Sb

51. Harris JL, Schwartz MB \& Brownell KD (2009) Marketing foods to children and adolescents: licensed characters and other promotions on packaged foods in the supermarket. Public Health Nutr 13, 409-417.

52. Wicks JL, Warren R, Fosu I et al. (2009) Dual-modality disclaimers, emotional appeals, and production techniques in food advertising airing during programs rated for children. J Advertising 38, 93-105.

53. Horgen K, Choate M \& Brownell K (2001) Television food advertising: targeting children in a toxic environment. In Handbook of Children and the Media, pp. 447-462 [DG Singer and JL Singer, editors]. Thousand Oaks, CA: SAGE Publications. Inc.

54. Powell LM, Szczypka G, Chaloupka FJ et al. (2007) Nutritional content of television food advertisements seen by children and adolescents in the United States. Pediatrics 120, $576-583$.

55. Dietz WH \& Gortmaker SL (1985) Do we fatten our children at the television set? Obesity and television viewing in children and adolescents. Pediatrics 75, 807-812.

56. Malik VS, Popkin BM, Bray GA et al. (2010) Sugarsweetened beverages, obesity, type 2 diabetes mellitus, and cardiovascular disease risk. Circulation 121, 1356-1364.

57. Natella S, Divan V, Rana M et al. (2013) Sugar Consumption at a Crossroads. Zurich: Credit Suisse AG Research Institute.

58. Anand SS, Hawkes C, De Souza RJ et al. (2015) Food consumption and its impact on cardiovascular disease: importance of solutions focused on the globalized food system: a report from the workshop convened by the World Heart Federation. J Am Coll Cardiol 66, 1590-1614.

59. Ministerio de Justicia y Derechos Humanos, Presidencia de la Nación (1993) Ley de Defensa del Consumidor $\mathrm{N}^{\circ} 24.240$ (Consumer Protection Law). https://goo.gl/Ajqh8M (accessed July 2017)

60. Ministerio de Justicia y Derechos Humanos, Presidencia de la Nación (2009) Ley de Servicios de Comunicación Audiovisual $\mathrm{N}^{\mathrm{o}} 26.522$ (Audiovisual Communication Services Law). http://servicios.infoleg.gob.ar/infoleg Internet/anexos/155000-159999/158649/norma.htm (accessed October 2016).

61. Ministerio de Justicia y Derechos Humanos, Presidencia de la Nación (1983) Ley de Lealtad Comercial N $\mathrm{N}^{\circ} 22.802$ (Commercial Loyalty Law). http://servicios.infoleg.gob. ar/infolegInternet/anexos/15000-19999/19946/texact.htm (accessed October 2016).

62. National Drug, Food and Medical Technology Administration (2015) Disposition $N^{\circ}$ 6516. http://www.anmat.gov.ar/ boletin_anmat/BO/Disposicion_6516-2015.pdf （accessed October 2016).

63. Adams J, Tyrrell R, Adamson AJ et al. (2012) Effect of restrictions on television food advertising to children on exposure to advertisements for 'less healthy' foods: repeat cross-sectional study. PLoS One 7, e31578.

64. Saffer H \& Chaloupka F (2000) The effect of tobacco advertising bans on tobacco consumption. $J$ Health Econ 19, 1117-1137. 